\title{
EFFECT OF PSAK 72 IMPLEMENTATION IN PROPERTY AND REAL ESTATE'S FINANCIAL HEALTH
}

\author{
Juni Fransisca \\ Ahalik \\ Sekolah Tinggi Manajemen PPM \\ junifransisca1206@gmail.com \\ ahalikcpa@gmail.com
}

\section{A R T I C L E I N F O \\ Article history: \\ Received: 12 November 2021 \\ Revised: 22 December 2021 \\ Accepted: 3 January 2022}

Keywords:

Net Profit Margin; PSAK 72; Springate;

Taffler; Total Asset Turnover

DOI:

https://doi.org/10.33508/rima.v4i2.3529

\begin{abstract}
A B S T R A C T
PSAK 72 is set to become a single standard regulating revenue recognition and is effective starting January 1st, 2020. This standard has a significant impact on the property and real estate sectors. This study aims to compare the company's financial health before and after the application of PSAK 72 using the Springate and Taffler models. The ratios used to measure the comparison of income in this study are net profit margin and total asset turnover. The population used in the company's property and real estate listed on the Indonesia Stock Exchange in 2019-2020. By using a purposive sampling method, the research sample obtained 31 companies. The analytical tool used in this test is the Wilcoxon signed-rank test. The results showed a significant decrease in net profit margin and total asset turnover between before and after the implementation of PSAK 72 and the effect on financial health as measured by the Springate and Taffler models.
\end{abstract}

\section{INTRODUCTION}

Profitability is an important determinant of a company's performance. The level of business continuity is very important to build the national economy. Income must be recognized by the applicable Statement of Financial Accounting Standards (SFAS). In 2017, the Indonesian Accounting Association published PSAK 72 for contract income with customers from January 1st, 2020. PSAK 72 is the only revenue recognition standard. It officially conforms to previous revenue recognition standards such as PSAK 23 for Revenue, PSAK 34 for Construction Contracts, PSAK 44 for Real Estate Development, ISAK 10 for Customer Loyalty, ISAK 21 for Real Estate Construction Agreement, and ISAK 27 for
Transfer on Assets from Customers (Ikatan Akuntansi Indonesia, 2018).

PSAK 72 has a difference from the previous PSAK in revenue recognition. The new standard provides that revenue is recognized not by the receipt of down payment but based on the contractual obligations the entity has performed to the customer under a mutually agreed upon contract. Recognized revenue is generated progressively over an agreed-upon contract period or at a specific time. Recognition of revenue, carried out incrementally, should be consistent with the requirements to increase the customer's assets and meet the entity's obligations under certain contracts. If it does not meet certain conditions, the net income can be recognized after delivering assets (at a point in time) (PWC, 2019). 
This change of standard significantly impacts companies whose transactions are in the form of long-term contracts. One of the industrial sectors affected by PSAK 72 is the real estate sector, where property developers will not get income before the handover. In the previous standards, revenue can be recognized even though it has not gone through the handover process, which means the company can directly recognize revenue even though the project from the purchased unit is still under construction. In the implementation of PSAK 72, new sales may be recognized in the financial statements after the handover is complete.

Throughout 2020, the performance of the real estate industry experienced positive growth of 2.32 percent. Although still showing a positive and better performance than some other industry sectors, the growth of the real estate industry in 2020 is still smaller than the growth of the real estate industry in 2019 (Data Industri, 2021). Property and real estate sector companies in Indonesia must compete in the face of any conditions. Unpreparedness and inability with the new standard change will cause business activities to be bad, and when the company cannot survive, it can result in its financial condition becoming unhealthy. The company's financial condition is presented in the form of financial statements.

Analysis of financial statements wants to know the level of profitability and the level of risk or the level of health of a company. The tool used to determine a company's financial health is the financial ratio. Analysis of financial ratios can give an idea of the good condition of a company. The financial ratio consists of profitability ratio, liquidity ratio, solvency ratio (leverage), and activity ratio. The ratio used to measure the ratio of income before and after the application of PSAK 72 in this study, namely the ratio of profitability (net profit margin) and activity ratio (total asset turnover).

The survival prediction of the company is made to find out the financial condition. Financial indicators are factors related to a company's financial condition as measured using Financial Discriminant Models. The model combines several financial ratios to describe a company's financial condition. Various analytical methods have been developed to predict the financial condition of a company, including those developed by Springate (1978), Ohlson (1980), and Taffler (1982). Springate's model is the latest in predicting financial conditions in cosmetic companies listed on the IDX with an accuracy rate of $91.66 \%$, compared to the Altman model with an accuracy rate of only $60.41 \%$ (Meiliawati \& Isharijadi, 2016).

In addition to the above research that said the Springate model is most accurate, the results of previous studies show that the Taffler model is the most appropriate model for predicting bankruptcy conditions with an accuracy value of $71 \%$ (Perwira, 2016). Compared to other models, Springate and Kida have an accuracy rate of $65 \%$, while Altman's accuracy rate is $41 \%$.

Given the importance of paying attention to the level of financial conditions for the company, it makes a special reason for the author to analyze the effect of the application of PSAK 72 on property and real estate companies to compare financial health before and after the implementation of PSAK 72 using the Springate model and the Taffler model.

Based on the background that has been spelled out above, the formulation of problems that can be studied is:

1. How does the financial health of property and real estate companies compare before and after the implementation of PSAK 72 using the Springate model?

2. How does the financial health of property and real estate companies compare before and after the implementation of PSAK 72 using the Taffler model? 


\section{LITERATURE REVIEW AND HYPOTHESIS DEVELOPMENT}

Signaling Theory

Signaling theory emphasizes the importance of information issued by companies to the decisions of external parties of the company (Godfrey et al., 2010). From this theoretical perspective, management voluntarily provides investors with information useful in assisting decision-making. The benefit of signaling theory is to describe the behavior of two parties (individuals or organizations) who have access to different information.

The sender of the information must think about communicating or signaling the information. On the other hand, the receiver must know how to interpret the signal (Connelly et al., 2011). The signaling theory in this study is that applying new financial accounting policies and standards in companies is one form of signal that can be given to outsiders. Applying new accounting policies and standards will signal that the company has transparency over its financial statements and has followed applicable accounting policies.

\section{Income}

Income is an increase in assets or decrease in liabilities increasing equity, in addition to those relating to investment contributions (Kieso et al., 2020). The income arises from a company's activities, such as sales, interest, dividends, and rent. Revenue recognition describes the transfer of goods or services to a customer at a price that reflects considerations the entity receives or will receive in return for such goods or services. In the accounting period, income is recognized when obligations have been met.

\section{PSAK 44: Accounting Of The Real Estate Development Activities}

In PSAK 44 (2014 Revised Edition), there are statements to regulate the accounting treatment for transactions specifically related to real estate development activities. This statement applies to companies that carry out real estate development activities, although real estate development activities are not the company's main activities. This statement applies to companies' financial statements conducting real estate development activities.

Revenue recognition is divided into five scopes, namely:

1. Sale of house buildings, shop-houses, and other similar buildings along with the land. The full accrual method recognizes the sales income of house buildings, shop-houses, and other similar buildings and land plots.

2. Recognition of profit when the full accrual method is not fulfilled. If a real estate transaction does not meet the criteria for profit recognition by the full accrual method, sales recognition is suspended, and the transaction is recognized by the deposit method until all accrual method usage criteria are met.

3. Seller involvement without transfer of risks and benefits of ownership.

4. Sale of condominium buildings, apartments, offices, shopping centers, and similar buildings and units in timesharing ownership. Sales revenue of condominium building units, apartments, offices, shopping centers, other similar buildings, and units in ownership on a time-sharing basis is recognized by the percentage of completion method.

5. Sale of land without buildings. Revenue sales of land without buildings, recognized using the full accrual method.

PSAK 72: Revenue From Contracts With Customers

In PSAK 72 (2018 Revised Edition), some statements aim to establish the principles applied by the company to convey information that is useful to the user of financial statements, including the amount, nature, and uncertainty associated 
with income arising from income from contracts with customers.

The scope of revenue recognition on PSAK 72 includes:

1. Identifying contracts

2. Contract Combination

3. Contract Modification

4. Identifying Implementation Obligations

5. Fulfillment of Implementation Obligations

\section{Financial Statements' Analysis}

In PSAK 1 (2015 Revised Edition), a financial statement is a structure that presents the financial position and financial performance of an entity. Financial statement analysis is a method or technique of analysis of financial statements that convert data derived from financial statements as raw material into more useful, more in-depth, and sharper information with certain techniques. In addition, a financial statement is analyzed to know the level of profitability and risk of company health. A financial ratio is a calculation of ratios using financial statements that serve as a measuring tool in assessing the company's financial condition (Hery, 2015).

Net profit margin influences a company's profit from each sale (Jumingan, 2017). There are lots of factors that affect profits from year to year. These factors are mainly in sales levels, changes in the cost of goods sold, and business costs. The higher the net profit margin, the higher the net profit generated from sales due to the high pre-income tax profits. Conversely, the lower the net profit margin means, the lower the net profit generated from sales.

According to Hani (2014), total asset turnover is the ratio used to measure the efficiency of overall asset use over a period. This ratio measures how far assets have been used in a company's activities or shows how many assets were used in operations in a single period. The average measurement for total asset turnover is twice to maximize assets owned by the company. If the company cannot maximize assets, it is expected to increase its sales or reduce some less productive assets (Kasmir, 2018).

\section{$\underline{\text { Prediction Model }}$}

To assess a company's finances, we can use the Financial Discriminant Models as the financial analysis. The model combines several financial ratios to describe a company's financial condition. These calculation models include Altman, Springate, Ohlson, Taffler, Zmijewski, and Grover. Several analysis models all come down to one goal: to know whether a company is in a healthy, gray, unhealthy area or experiencing bankruptcy. The Springate and Taffler models are selected because they have a ratio of sales to total assets and are relatively easy to use. In addition, based on the results of previous studies, both models have a fairly high level of accuracy in predicting a company's financial condition.

The Springate model was developed in 1978 by Gorgon L. V. Springate (Peter \& Yoseph, 2011). Springate researched to find a model that could predict potential or indicative of bankruptcy. Springate used nineteen popular financial ratios used to measure a company's bankruptcy. Springate's sample included 40 manufacturing companies in Canada, 20 companies experiencing financial difficulties, and 20 in good health. Springate eventually discovered and used four of the nineteen ratios that had a rate of $92.5 \%$. The four ratios are the ratio of working capital to total assets, the ratio of earnings before interest and taxes to total assets, the ratio of earnings before tax to total current liabilities, and the ratio of total sales to total assets.

Taffler's model was published in 1982. The construction of this model is based on the Altman model and discriminant analysis methods. The Taffler model is also used to predict a company's bankruptcy. There are four ratios used in this model, namely the ratio of earnings before tax to total current debt, the ratio of current assets to total 
liabilities, the ratio of current debt to total assets, and the ratio of total sales to total assets.

The hypothesis in this study are:

$\mathrm{H}_{1}$ : There is a significant net profit margin difference before and after the implementation of PSAK 72.

$\mathrm{H}_{2}$ : There is a significant difference in total asset turnover before and after the implementation of PSAK 72.

$\mathrm{H}_{3}$ : There are significant financial health differences before and after the implementation of PSAK 72 with the Springate model.

$\mathrm{H}_{4}$ : There are significant financial health differences before and after the implementation of PSAK 72 with the Taffler model.

\section{RESEARCH METHOD}

\section{Design, Population, And Sample}

The research design used is comparative research. Researchers compared data on the company's financial ratio before and after PSAK 72. The study uses quantitative approaches with appropriate statistical methods. This research is intended to find out the differences in financial health before and after the application of PSAK 72 in property and real estate companies listed on the Indonesia Stock Exchange from 2019 to 2020.

The population in this study is companies engaged in the property and real estate sector listed on the Indonesia Stock Exchange from 2019 to 2020, which amounted to 77 companies. Sampling techniques in this study use nonprobability sampling, which is purposive sampling. Thus, the results of the sample obtained are:

Table 1. Research Sample

\begin{tabular}{clc}
\hline No. & \multicolumn{1}{c}{ Criteria } & Total \\
\hline 1 & $\begin{array}{l}\text { Property and real estate companies listed on IDX during 2019-2020 } \\
2\end{array}$ & $\begin{array}{l}\text { Property and real estate companies that are on the main board on the } \\
\text { trading board on the exchange }\end{array}$ \\
3 & $\begin{array}{l}\text { Property and real estate companies that publish financial statements in } \\
\text { full during 2019-2020 } \\
\text { Total selected companies }\end{array}$ & $(42)$ \\
\hline
\end{tabular}

Source: Processing results by researchers (2021)

\section{Dependent Variable}

1. Springate Model

Springate uses financial ratios to measure four existing ratios to measure corporate bankruptcies. Springate's formula model with the term S-Score in Sinarti dan Sembiring (2015) research is as follows:

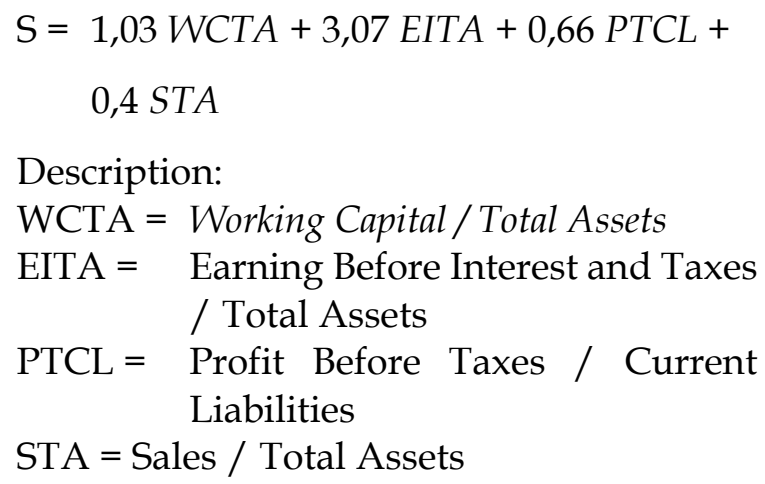$$
0,4 \text { STA }
$$

Description:

WCTA = Working Capital / Total Assets

EITA $=$ Earning Before Interest and Taxes / Total Assets

PTCL $=$ Profit Before Taxes $/$ Current Liabilities

STA $=$ Sales $/$ Total Assets

A healthy company classification based on Springate's model, namely:

a. The value of $S<0.862$ indicates that the company is experiencing an unhealthy financial condition.

b. With the value of $S>0.862$, the company is in a healthy financial condition.

2. Taffler Model

The Taffler model is also used to predict a company's bankruptcy. The formula model produced by Hajek et al. (2017) is as follows:

$$
\begin{aligned}
\mathrm{TZ} & =0,53 \mathrm{PTCL}+0,13 \mathrm{CATL}+0,18 \mathrm{CLTA} \\
& +0,16 \mathrm{STA}
\end{aligned}
$$

Description: 


$$
\begin{aligned}
& \text { PTCL }= \text { Profit Before Taxes } / \text { Current } \\
& \text { Liabilities } \\
& \text { CATL }=\text { Current Assets } / \text { Total Liabilities } \\
& \text { CLTA }=\text { Current Liabilities } / \text { Total Assets } \\
& \text { STA }=\text { Sales } / \text { Total Assets }
\end{aligned}
$$

The conclusions of the Taffler model are as follows:

a. If the TZ value is $>0.3$, the company is healthy financially.

b. If the value is $0.2<\mathrm{TZ}<0.3$, the company is in the grey zone.

c. If the value of $\mathrm{TZ}<0.2$, then the company is experiencing an unhealthy financial condition.

\section{Independent Variable}

\section{Net Profit Margin}

Net profit margin is a more specific measurement of the profitability ratio relating to the sale of a company after accounting for all costs and taxes. The formula for measuring this ratio is as follows:

\section{Total Asset Turnover}

$$
N P M=\frac{\text { Net Income }}{\text { Sales }}
$$

Total asset turnover is a ratio that measures how a company efficiently utilizes all assets owned by the company by creating sales to generate profits. The formula for measuring this ratio is as follows:

$$
T A T O=\frac{\text { Sales }}{\text { Total Asset }}
$$

\section{Data Collection Methods}

The data collection methods used are methods of documentation and literature studies. The documentation method is a method that uses data in the form of documents. Documentation methods are done by collecting, recording, and calculating data related to research (Jayati, 2016). While the literature study collects information and data in depth through various literature, books, and the results of previous relevant research, in this study, researchers used financial statements of property and real estate companies listed on the Indonesia Stock Exchange that have been audited and can be accessed through the official IDX website.

\section{Data Analysis Methods}

Data analysis by the author starts from the calculation, processing, and analysis with the help of the SPSS software program version 22 to test the research model. Data analysis in this study was conducted in several stages; namely, financial discriminant models calculations, normality tests, and Wilcoxon Signed Rank Test to test hypotheses.

\section{RESULT AND DISCUSSION}

Normality Test

Table 2. Normality Test

\begin{tabular}{llrr}
\hline & & $\begin{array}{c}\text { Unstandardized } \\
\text { Residual S }\end{array}$ & $\begin{array}{c}\text { Unstandardized } \\
\text { Residual TZ }\end{array}$ \\
\hline$N$ & & 62 & 62 \\
Normal Parametersa,b & Mean & .0000000 & .0000000 \\
& Std. Deviation & .44175649 & .45011467 \\
Most Extreme Differences & Absolute & .126 & .258 \\
& Positive & .126 & .258 \\
Test Statistic & Negative & -.095 & -.151 \\
Asymp. Sig. (2-tailed) & & .126 & .258 \\
\hline a. Test distribution is Normal. & & .016 & .000 c \\
b. Calculated from data. & & & \\
c. Lilliefors Significance Correction. & & &
\end{tabular}

Source: Processing results by researchers (2021) 
Based on the normality test results in Table 2, the significance value (2-tailed) of 0.016 for the Springate model dependent variable and by 0.000 for the Taffler model dependent variable can be seen. This result indicates that the data is not normally

Hypothesis Test

1. Difference In Net Profit Margin Before And After Implementation of PSAK 72

Table 3. Ranks - NPM

\begin{tabular}{llrrr}
\hline & $\mathrm{N}$ & Mean Rank & Sum of Ranks \\
\hline $2020-2019$ & Negative Ranks & $24^{\mathrm{a}}$ & 19.00 & 456.00 \\
& Positive Ranks & $7^{\mathrm{b}}$ & 5.71 & 40.00 \\
& Ties & $0 \mathrm{c}$ & & \\
& Total & 31 & & \\
\hline
\end{tabular}

a. $2020<2019$

b. $2020>2019$

c. $2020=2019$

Source: Processing results by researchers (2021)

Based on the results in table 3 , it is seen that negative ranks generate 24 data, which means that 24 companies are experiencing a decrease in net profit margin.

Positive ranks generate 7 data, which means that seven companies experience an increase in net profit margin before and after PSAK 72 . distributed because the significance level is smaller than 0.05 . Therefore, this study uses the Wilcoxon signed-rank test.

Table 4. Wilcoxon Signed Rank Test - NPM

\begin{tabular}{ll}
\hline & $2020-2019$ \\
\hline$Z$ & $-4.076^{\mathrm{b}}$ \\
Asymp. Sig. (2-tailed) & .000 \\
\hline
\end{tabular}

a. Wilcoxon Signed Ranks Test

b. Based on positive ranks.

Source: Processing results by researchers (2021)

Based on the results in Table 5, it is seen that negative ranks generate 24 data, which means that 24 companies are experiencing a decrease in total asset turnover. Positive
Based on the results in table 4 , we can see a significance value (2-tailed) of $0.000<0.05$. Thus, it can be concluded that there is a significant net profit margin difference between before and after the implementation of PSAK 72. ranks generate 7 data, meaning that seven companies experience an increase in total asset turnover between before and after PSAK 72. 
Table 5. Ranks - TATO

\begin{tabular}{llrrr}
\hline & $\mathrm{N}$ & Mean Rank & Sum of Ranks \\
\hline $2020-2019$ & Negative Ranks & $24^{\mathrm{a}}$ & 16.17 & 388.00 \\
& Positive Ranks & $7 \mathrm{~b}$ & 15.43 & 108.00 \\
& Ties & $0 \mathrm{c}$ & & \\
& Total & 31 & & \\
\hline
\end{tabular}
a. $2020<2019$
b. $2020>2019$
c. $2020=2019$

Source: Processing results by researchers (2021)

2. Difference in Total Asset Turn Over Before and After Implementation of PSAK 72

Table 6. Uji Wilcoxon Signed Rank Test - TATO

\begin{tabular}{lr} 
& $2020-2019$ \\
\hline$Z$ & $-2.744^{\mathrm{b}}$ \\
Asymp. Sig. (2-tailed) & .006 \\
\hline a. Wilcoxon Signed Ranks Test & \\
b. Based on positive ranks. &
\end{tabular}

Source: Processing results by researchers (2021)

Based on the results in Table 6, it can be seen that the significance value (2-tailed) of $0.006<0.05$. It can be concluded that there is a significant difference in total asset turnover between before and after the implementation of PSAK 72.

3. Differences in Financial Health Before and After The Implementation of PSAK 72 with Springate Model

Based on the results in table 7 , it is seen that negative ranks produce 24 data, which means that 24 companies are experiencing a decline in financial health. Positive ranks generated 7 data, which means that 7 data experienced increased financial health between before and after PSAK 72 using the Springate model.

Based on the results in table 8 , we can see a significance value (2-tailed) of $0.000<$ 0.05 . It was concluded that there was a significant difference in financial health between before and after PSAK 72 using the Springate model.

Table 7. Ranks - S

\begin{tabular}{llrrr}
\hline & $\mathrm{N}$ & Mean Rank & Sum of Ranks \\
\hline $2020-2019$ & Negative Ranks & $24^{\mathrm{a}}$ & 17.94 & 430.50 \\
& Positive Ranks & $7 \mathrm{~b}$ & 9.36 & 65.50 \\
& Ties & $0^{\mathrm{c}}$ & & \\
& Total & 31 & & \\
\hline
\end{tabular}
a. $2020<2019$
b. $2020>2019$
c. $2020=2019$ 
4. Differences in Financial Health Before and After The Implementation of PSAK 72 with Taffler Model

Table 8. Wilcoxon Signed-Rank Test - S

\begin{tabular}{lr}
\hline & $2020-2019$ \\
\hline$Z$ & $-3.576^{\mathrm{b}}$ \\
Asymp. Sig. (2-tailed) & .000 \\
\hline $\begin{array}{l}\text { a. Wilcoxon Signed Ranks Test } \\
\text { b. Based on positive ranks. } \quad \text { Source: Processing results by researchers (2021) }\end{array}$
\end{tabular}

Based on the results in table 9 , it is seen that negative ranks produce 25 data, which means that 25 companies are experiencing a decline in financial health. Positive ranks generated six positive data, which means that 6 data experienced an increase in financial health between before and after PSAK 72 using the Taffler model.
Based on the results in table 10, we can see a significance value (2-tailed) of $0.000<$ 0.05 . Thus, it can be concluded that there is a significant difference in financial health between before and after the implementation of PSAK 72 using the Taffler model.

Table 9. Ranks - TZ

\begin{tabular}{llrcr}
\hline & & \multicolumn{2}{c}{ Mean } & \\
& & Rank & Sum of Ranks & 433.00 \\
\hline $2020-2019$ & Negative Ranks & $25^{\mathrm{a}}$ & 17.32 & \\
& Positive Ranks & $6^{\mathrm{b}}$ & 10.50 & \\
& Ties & $0^{\mathrm{c}}$ & & \\
& Total & 31 & & \\
\hline
\end{tabular}
a. $2020<2019$
b. $2020>2019$
c. $2020=2019$

Source: Processing results by researchers (2021)

Table 10. Wilcoxon Signed Rank Test - TZ

\begin{tabular}{|c|c|}
\hline & \\
\hline $\bar{Z}$ & $-3.625^{b}$ \\
\hline Asymp. Sig. (2-tailed) & .000 \\
\hline
\end{tabular}

\section{Hypothesis Discussion}

1. The difference in Net Margin Before and After Implementation of PSAK 72

Results showed a significant net profit margin (NPM) difference between before and after the implementation of PSAK 72. This difference is known from the results of NPM 24 companies in 2020 decreased compared to 2019. The lowest NPM in 2019 was experienced by PT Duta Anggada Realty Tbk. of -0.56 , while in 2020, it was experienced by PT DMS Propertindo Tbk. of -4.39 .

The decline in NPM in 2020 illustrates low net profit margins at the 24 companies sampled by the study. In general, the 
company experienced a drastic decrease in net sales due to PSAK 72. NPM drops quite significantly because revenue from longterm contracts has considerable value if revenue is not recognized, resulting in a decrease in the company's level of income and net income, in line with research conducted by Veronica et al. (2019) and Agustrianti et al. (2020), which said the calculation of net profit margin showed a percentage decrease when using PSAK 72 compared to PSAK 44.

2. The difference in Total Asset Turn Over Before and After Implementation of PSAK 72

Results showed a significant difference in Total Asset Turn Over (TATO) between before and after the implementation of PSAK 72. This difference is known from the results of TATO 24 companies in 2020 decreased compared to 2019. The lowest TATO in 2019 was experienced by PT Greenwood Sejahtera Tbk. of 0.0116, while in 2020, it was experienced by PT DMS Propertindo Tbk. of 0.0043 .

The decline in TATO in 2020 proves the low turnover of assets managed to support sales at 24 sample companies, due to PSAK 72 applying at a point in time, so that real estate companies experience a slight decrease in the efficiency of their assets. The results of this study contradict the results of a study conducted by Halim \& Herawati (2020), which showed that the application of PSAK 72 as measured by TATO had an insignificant negative influence.

3. Differences in Financial Health Before and After The Implementation of PSAK 72 with Springate Model

Results showed a significant difference in financial health between before and after PSAK 72 using the Springate model. This difference is known from the results of statistical tests showing that 24 companies in 2020 experienced a decrease in financial condition compared to 2019. The lowest financial health in 2019 was experienced by PT Duta Anggada Realty Tbk. of -0.2730 , while in 2020, it was experienced by PT Lippo Cikarang Tbk. of -1.1098.

Prior to PSAK 72, 19 companies were experiencing unhealthy financial conditions, and 12 companies had healthy financial conditions. While after the implementation of PSAK 72, it is known that only four companies have a healthy financial condition and 27 other companies experience unhealthy financial conditions.

4. Differences in Financial Health Before and After The Implementation of PSAK 72 with Taffler Model

Results showed a significant difference in financial health between before and after PSAK 72 using the Taffler model. This difference is known from the results of statistical tests showing that 25 companies in 2020 experienced a decrease in financial condition compared to 2019. The lowest financial health in 2019 was experienced by PT Ristia Bintang Mahkotasejati Tbk. of 0.0479 , while in 2020, experienced by PT Plaza Indonesia Realty Tbk. of -0.5640 .

Before implementing PSAK 72, 7 companies experienced unhealthy financial conditions, nine companies in the grey zone, and 15 companies had a healthy financial condition. While after the implementation of PSAK 72, it is known that 16 companies are experiencing unhealthy financial conditions, six companies are in the grey zone, and nine companies have a healthy financial condition.

\section{CONCLUSIONS}

The decrease in NPM and TATO due to PSAK 72 affects financial health as measured using the Springate model. Results showed that 24 companies in 2020 experienced a decrease in financial condition compared to 2019. Prior to PSAK 72, there were 19 companies with poor financial conditions, while 12 other firms had healthy financial soundness. After the PSAK 72 implementation, four companies with healthy financial conditions and 27 other unsound companies were reported. 
The reduction in NPM and TATO due to PSAK 72 affects financial health as measured by the Tuffler model. As a result, 25 companies were found to have deteriorated financial status as of 2020 compared to 2019. Prior to PSAK 72, seven firms were in bad financial condition, 9 in the grey area, and 15 in the good financial soundness. After implementation, it was reported that 16 companies were in poor financial conditions, six were in a grey area, and nine were in good financial condition.

Based on the results of this study, several suggestions can be made for future study, including adding other variables to the PSAK 72-related studies, such as the current liquidity ratio and debt ratio.

\section{REFERENCE}

Agustrianti, W., Mashuri, A. A. S., dan Nopiyanti, A. (2020). Dampak Penerapan PSAK 72 terhadap Kinerja Keuangan Perusahaan Property, Real Estate, and Building Construction yang Terdaftar di Bursa Efek Indonesia Tahun 2018-2019. Prosiding Business Management, Economic, and Accounting National Seminar, 1, 973-989.

Connelly, B. L., Certo, S. T., Ireland, R. D., dan Reutzel, C. R. (2011). Signaling Theory: a Review and Assessment. Journal of Management, 37(1), 39-67.

Data Industri. (2021). Tren Data Pertumbuhan Industri Real Estate (Properti) 2011-2021. Diakses pada 29 Juni 2021, dari https://www.dataindustri.com/produ $\mathrm{k} /$ tren-data-pertumbuhan-industrireal-estate-properti-2010-2021/

Godfrey, J., Hodgson, A., Tarca, A., Hamilton, J., dan Holmes, S. (2010). Accounting Theory (7 $7^{\text {th }}$ Edition). Australia: Wiley.

Hajek, P., Zhunissova, G., Cabelova, T., dan Baidildina, A. (2017). Competitiveness Analysis of Kazakhstan Confectionary Sector Using Financial Discriminant
Models. CBU International Conference on Innovations in Science and Education, 5, 145-154.

Halim, C. N. dan Herawati, T. D. (2020). Pengaruh Implementasi Pengakuan Pendapatan PSAK 72 terhadap Kinerja Keuangan (Studi Empiris pada Perusahaan Real Estate Tahun 2018-2019). Skripsi. Malang: Program Studi Akuntansi Fakultas Ekonomi dan Bisnis Universitas Brawijaya

Hani, S. (2014). Teknik Analisa Laporan Keuangan. Medan: In Media

Hery. (2015). Analisis Kinerja Manajemen. Jakarta: PT. Grasindo.

Ikatan Akuntansi Indonesia. (2014). Standar Akuntansi Keuangan No. 44: Akuntansi Aktivitas Pengembangan Real Estate. Jakarta: Dewan Standar Akuntansi Keuangan Ikatan Akuntansi Indonesia.

Ikatan Akuntansi Indonesia. (2015). Standar Akuntansi Keuangan No. 1: Penyajian Laporan Keuangan. Jakarta: Dewan Standar Akuntansi Keuangan Ikatan Akuntansi Indonesia.

Ikatan Akuntansi Indonesia. (2018). Standar Akuntansi Keuangan No. 72: Pendapatan dari Kontrak dengan Pelanggan. Jakarta: Dewan Standar Akuntansi Keuangan Ikatan Akuntansi Indonesia.

Jayati, S. E. (2016). Pengaruh Intellectual Capital terhadap Kinerja Keuangan Perusahaan Perdagangan Jasa yang Terdaftar di Bursa Efek Indonesia. Skripsi. Universitas Negeri Yogyakarta

Jumingan. (2017). Analisis Laporan Keuangan. Jakarta: PT. Bumi Aksara

Kasmir. (2018). Analisis Laporan Keuangan. Depok: Rajawali Pers.

Kieso, D. E., Weygandt J. J., dan Warfield T. D. (2020). Intermediate Accounting: IFRS 
Edition (4th $E d)$. United States Of America: John Wiley \& Sons, Inc.

Meiliawati, A. dan Isharijadi. (2016). Analisis Perbandingan Model Springate dan Altman Z Score terhadap Potensi Financial Distress (Studi Kasus pada Perusahaan Sektor Kosmetik yang Terdaftar di Bursa Efek Indonesia). Jurnal Akuntansi dan Pendidikan, (1).

Perwira, V. V. Y. (2016). Evaluasi Keakurasian Prediksi Kondisi Bankruptcy. Skripsi. Yogyakarta: Program Studi Akuntansi Fakultas Ekonomi Universitas Sanata Dharma

Peter dan Yoseph. (2011). Analisis Kebangkrutan dengan Metode Z-Score Altman, Springate, dan Zmijewski pada PT. Indofood Sukses Makmur Tbk. Periode 2005-2009. Jurnal Ilmiah Akuntansi, (4).
PWC. (2019). Standar Akuntansi Baru Berlaku 2020. Diakses pada 30 Juni 2021, dari https://www.pwc.com/id/en/mediacentre/pwc-innews/2019/indonesian/standarakuntansi-baru-berlaku-2020.html

Sinarti dan Sembiring. (2015). Bankruptcy Prediction Analysis of Manufacturing Companies Listed in Indonesia Stock Exchange. International Journal of Economics and Financial Issues, 5, 354-359.

Veronica, Lestari, U. P., dan Metekohy, E. Y. (2019). Analisis Dampak Penerapan Pengakuan Pendapatan Berdasarkan PSAK 72 terhadap Kinerja Keuangan Perusahaan Real Estate di Indonesia yang Terdaftar di Bursa Efek Indonesia Tahun 2018. Prosiding Industrial Research Workshop and National Seminar, 10(1), 965-973. 